\title{
WHALESUCKERS AND A SPINNER DOLPHIN BONDED FOR WEEKS: DOES HOST FIDELITY PAY OFF?
}

\author{
José Martins Silva-Jrl and Ivan Sazima² \\ Biota Neotropica v3 (n2) http://www.biotaneotropica.org.br/v3n2/pt/abstract?short-communication+BN01303022003 \\ Date Received 07/16/2003 \\ Revised 09/30/2003 \\ Accepted 10/24/2003 \\ ${ }^{1}$ Centro Golfinho Rotador, CP 49, 53990-000 Fernando de Noronha, Pernambuco, Brazil \\ (www.golfinhorotador.org.br), and Departamento de Oceanografia, Universidade Federal de Pernambuco \\ ${ }^{2}$ Departamento de Zoologia and Museu de História Natural, CP 6109, Universidade Estadual de Campinas, 13083-970 \\ Campinas, São Paulo, Brazil (www.unicamp.br) \\ Corresponding author. Tel: + 55-19-3788 7292; fax: +55-19-32893124; e-mail: isazima@unicamp.br
}

\begin{abstract}
The whalesucker Remora australis (Echeneidae) is an oceanic diskfish found attached to cetaceans only and its habits are therefore poorly known. At the Fernando de Noronha Archipelago, off North-eastern Brazil, spinner dolphins Stenella longirostris (Delphinidae) regularly congregate in large groups in a shallow bay, which allows for underwater observations of their behaviour and their fish associates. In the course of a broader study of this elusive diskfish, we had the opportunity to made multiple records of two whalesucker couples (three of the fish naturally marked) attached to the same individual dolphin in two different years, over periods of 47 and 87 days respectively. In all the sightings the whalesucker individuals of a couple were recorded side-by-side and positioned on their host's belly. We surmise that at least one of the couples was a reproductive pair, as the belly of the larger fish was noticeably swollen in the last sighting, and the bulge on its belly was bilateral and extended almost uniformly to the vent, a strong indication of fully mature gonads. Moreover, its size matched those of the mature females of this diskfish species. To our knowledge, this is the first time that attachment fidelity of the whalesucker to any cetacean host is documented in the wild. We hypothesize that attachment fidelity to the same individual host increases the whalesucker's chance to mate, and suggest further that the highly social nature of the spinner dolphins facilitates encounters between potential mating partners. Our study indicates that host fidelity possibly is not an uncommon feature of the whalesucker behaviour, albeit difficult to recognise. In one of the above recorded whalesuckers the natural marking was a crescentic scar characteristic of the wounds inflicted by the cookiecutter Isistius brasiliensis (Dalatiidae), a first record of the attack of this shark to any diskfish species.
\end{abstract}

Key words: Fish-cetacean association, host attachment fidelity, mate finding, Echeneidae, Delphinidae,Southwestern Atlantic

Resumo - A rêmora-das-baleias Remora australis (Echeneidae) é um peixe-pegador oceânico que vive agarrada somente a cetáceos, sendo seus hábitos mal conhecidos devido a esta característica. No Arquipélago de Fernando de Noronha, ao largo do Nordeste do Brasil, os golfinhos-rotadores Stenella longirostris (Delphinidae) congregam-se regularmente em grandes grupos numa baía rasa, o que permite o estudo subaquático de seu comportamento e dos peixes associados. Ao longo de um estudo amplo deste peixe-pegador pouco conhecido, tivemos a oportunidade de fazer registros múltiplos de dois pares de rêmoras (três delas com marcas naturais), agarradas ao mesmo golfinho em dois anos distintos, por períodos de 47 e 87 dias, respectivamente. Em todas as observações, os indivíduos de cada par de rêmoras foram registrados um ao lado do outro e posicionados no ventre do hospedeiro. Supomos que pelo menos um dos pares fosse um casal reprodutivo, pois o ventre do indivíduo maior apresentava saliência bilateral bem perceptível, que se estendia até o orifício cloacal, uma característica de fêmeas com gônadas maduras. Além disso, este indivíduo apresentava comprimento correspondente ao de fêmeas maduras desta espécie. Até onde sabemos, esta é a primeira vez que a fidelidade de associação desta espécie de rêmora a qualquer cetáceo é documentada na natureza. Propomos aqui que a fidelidade de associação ao mesmo hospedeiro aumente a possibilidade da rêmora se reproduzir. Adicionalmente, sugerimos que a natureza altamente social dos golfinhosrotadores facilite o encontro entre parceiros para reprodução. Os nossos registros indicam que a fidelidade ao hospedeiro possivelmente não seja um componente incomum do comportamento da rêmora-das-baleias, embora difícil de reconhecer. Numa das rêmoras registradas, a marca natural era uma cicatriz em forma de meia-lua, característica da mordida causada pelo tubarão-charuto Isistius brasiliensis (Dalatiidae), primeiro registro de ataque deste tubarão a uma espécie de rêmora.

Palavras-chave: Associação entre peixes e cetáceos, fidelidade ao hospedeiro, encontro entre parceiros, Echeneidae, Delphinidae, Atlântico Sudoeste 


\section{Introduction}

Remoras or diskfishes (Echeneidae) attach to several types of marine vertebrates, from sharks to cetaceans (Cressey and Lachner, 1970; Fertl and Landry, 1999). Remoras may benefit from this association in several ways, such as ride, feeding, and protection from predators (Strasburg, 1959; Cressey and Lachner, 1970; Alling, 1985; Katona \& Whitehead, 1988). Whereas some diskfish species attach to a broad array of hosts, other species are prone to attach to particular host types. For instance, a hostspecialised remora is the whalesucker (Remora australis) which, as its common name indicates, lives attached to cetaceans only, and thus its habits are poorly known (Follett \& Dempster, 1960; Rice \& Caldwell, 1961; Radford \& Klawe, 1965).

At the Fernando de Noronha Archipelago, Southwestern Atlantic, the spinner dolphins Stenella longirostris longirostris (Delphinidae) regularly congregate in a shallow bay (Lodi and Fiori, 1987; Silva-Jr., 1996), offering ideal conditions for underwater observations of their behaviour (Silva-Jr., 1996; Sazima et al., 2003). As the whalesucker is one of the habitual fish associates of the spinners in the bay (Sazima et al., 2003), we started a medium-term (two years) study of this elusive diskfish to obtain a general view of its habits, and to gain some insight on what possible advantages this diskfish may obtain from its association with the cetacean. Besides seeking a general view of the whalesucker-dolphin association over our study, we tried to answer two more specific questions, based on an initial impression that some individual dolphins carried their "own" whalesuckers for extended periods: 1) For how long an individual whalesucker may attach itself to the same dolphin? 2) Is there any advantage for the whalesucker in doing so? This paper relates to these questions, and reports on two well-documented instances of whalesuckers-dolphin individual bond.

\section{Material and Methods}

The study was conducted at the Fernando de Noronha Archipelago (0350'S, $32^{\circ} 25^{\prime} \mathrm{W}$ ), about $345 \mathrm{~km}$ off North-eastern Brazil (see Maida \& Ferreira, 1997; Carleton \& Olson, 1999, for map and description). Observations were made in the Baía dos Golfinhos or Enseada do Carreiro de Pedra, a 15-25 m deep bay used by the spinner dolphins for resting and social interactions (Lodi \& Fiori, 1987; Silva-Jr., 1996). The bay is an intangible protected area of the Fernando de Noronha National Marine Park. The association between whalesuckers and dolphins was observed directly and photographed during snorkelling and passive diving over 108 days (1-5 days distributed monthly from September 2000 to March 2003). Observations were concentrated in the morning, the best period for behavioural observations of spinner dolphins (Silva-Jr., 1996; Sazima et al., 2003). During obser- vational sessions of 35-70 min, 'focal animal' and 'all occurrences' samplings were used in $71 \mathrm{~h}$ of direct observation in which all occurrences of specified actions of the whalesuckers (e.g., moving over the host body) over a given period were recorded (Altmann, 1974; Lehner 1979).

To answer our main question (i.e., that an individual whalesucker associate with a particular dolphin individual for an extended period), we needed reliable individual identifications of both the dolphins and the whalesuckers. Photo-identification of small cetaceans is a widespread procedure to identify individuals by natural marks such as fin shapes, nicks, scars, and pigment patterns (Würsig \& Jefferson, 1990) and has been successfully used to identify individual spinner dolphins in the Pacific (Norris et al., 1994) and the Atlantic (Silva-Jr., 1996). On the other hand, such marks are much more difficult to find on a whalesucker, a slate grey fish that spends most of its time underneath its host. However, three whalesucker individuals bore unmistakable natural marks (see below) that allowed us to identify them.

Total length (TL) of whalesuckers was conservatively estimated against the greater width of the host's pectoral fluke, which in one of our largest spinner dolphins $(1.87 \mathrm{~m}$ TL) measured $10 \mathrm{~cm}$. We surmised that any fish smaller than its host's pectoral fluke width was smaller than $10 \mathrm{~cm}$ TL, and similar relationships (e.g., dolphin's dorsal fin height) were used to estimate the size of larger fish. Voucher photographs (paper copies) of whalesuckers and spinner dolphins with natural marks are in the file of photo-identified individuals housed at the Centro Golfinho Rotador in Fernando de Noronha, and selected scanned photographs are on file at the Museu de História Natural, Universidade Estadual de Campinas (ZUEC).

\section{Results and Discussion}

In two well-documented instances we had the opportunity to verify our assumption that some individual whalesuckers associate to the same individual dolphin for periods up to about three months. The longest association period lasted 87 days, and was recorded on three occasions (15 September; 7 and 11 December 2000). The dolphin measured about $1.8 \mathrm{~m}$ TL (probably a male) and bore a series of nicks on the posterior edge of the dorsal fin. The naturally marked whalesucker was recognised by its crooked vertebral column and measured about $26 \mathrm{~cm}$ TL, a clear underestimate due to its distorted body This whalesucker was accompanied by an individual of about $32 \mathrm{~cm}$ TL, which bore no natural marks and thus was unrecognisable as the same individual on the three sightings.

The second instance relates to a shorter bond (74 days) but involves a couple of recognisable whalesuckers (Fig. 1), recorded on four occasions. The first and second sightings were on 11 and 14 December 2002, the third one 
was on 14 February 2003, and the final record was on 5 March 2003. The dolphin was the same individual of the first description. In the first sighting the larger whalesucker (about $55 \mathrm{~cm}$ TL) bore a fresh, characteristic crescentic wound caused by a cookiecutter shark on its right flank, which progressively healed to a still visible crescentic scar and a small protuberance (see Jones, 1971 for wound illustrations). The other whalesucker (about $45 \mathrm{~cm} \mathrm{TL}$ ) had a dark pigmented, elongate marking on its right side close to the belly. As the dolphin in the both above described instances was the same individual, this implies that in some moment between 11 December 2000 and 11 December 2002 it either acquired a new remora couple or at least one of its whalesuckers was replaced.

Cookiecutters are known to attack several cetacean species, including spinner dolphins (see Gasparini \& Sazima, 1996 for a review in the SW Atlantic), and this seems to be the first record of a cookiecutter shark biting a whalesucker or any other diskfish species (Jones, 1971; Tomás \& Gomes, 1989). In the large file of photo-identified spinner dolphins housed at the Centro Golfinho Rotador, we found another whalesucker individual wounded by a cookiecutter shark.

Both whalesuckers of the latter instance described herein were adults (see Radford \& Klawe, 1965), and in all sightings the fish were side-by-side and positioned on their host's belly. We surmise that this particular couple was a

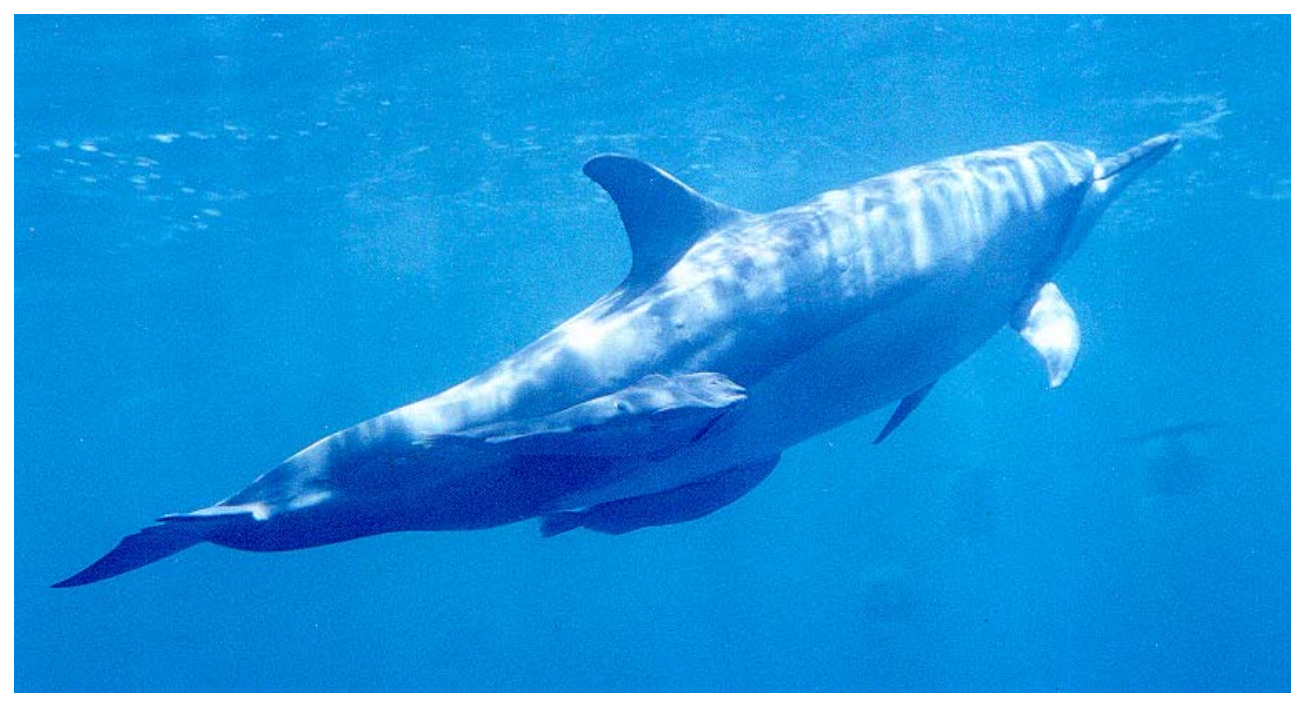

Fig. 1. A spinner dolphin (Stenella longirostris) at Fernando de Noronha Archipelago, SW Atlantic, with a couple of whalesuckers (Remora australis) attached to its body. All the members of the trio had natural marks, allowing their unmistakable recognition on four occasions over a period of 74 days.

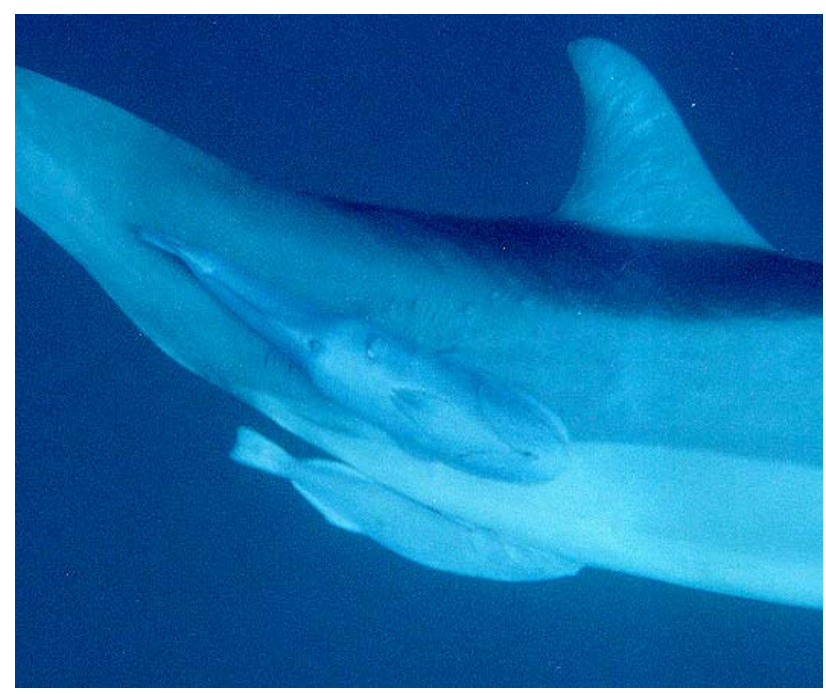

Fig. 2. The same whalesucker couple attached to the hind-body of the same spinner dolphin seen on Fig 1. On this last record (5 March 2003), the bilateral bulge seen on the belly of the larger suckerfish strongly indicates a ripe female. 
reproductive pair, as the belly of the larger fish was noticeably swollen in the last sighting, and its size matched those of the few mature females recorded to date (Radford \& Klawe, 1965). The swelling on the belly of the supposed female was bilateral and extended almost uniformly to the vent (Fig. 2), a strong indication of fully mature gonads (Helfman et al., 1997).

To our knowledge, this is the first time that attachment fidelity of the whalesucker to any cetacean host is documented in the wild. Moreover, there is a reasonable possibility that the second recorded fish couple was a prospective mating pair (see above). Host fidelity would increase pair bonding and mating chance due to the closeness of two adult individuals of opposite sex, which in itself may induce gonad maturation (Helfman et al., 1997). Thus, we hypothesise that attachment fidelity to the same individual host increase the whalesucker's mating chance, and suggest further that the highly social nature of the spinner dolphins (Norris et al., 1994) facilitate encounters between potential mating partners. The fact that the same dolphin individual changed at least one of its whalesuckers (perhaps even acquired a new couple) over a period of two years, lends some support to this latter suggestion. Notwithstanding the fact that our assumptions are based on only one individually recognisable spinner dolphin, we suspect that the bond type recorded here would not be uncommon but is likely to go undetected due to our inability to recognise whalesucker individuals.

\section{Acknowledgements}

We thank the student staff of the Centro Golfinho Rotador, as well as the field helpers for logistic support and help in the fieldwork; C. Sazima for comments on the manuscript; the Ibama for issuing permits to study spinner dolphins and reef fishes in the Fernando de Noronha National Marine Park; the CAPES, CNPq, FAEP-Unicamp, FAPESP, Fundo Nacional do Meio Ambiente (FNMA/MMA), and Petrobras for essential financial support throughout the study.

\section{References}

ALTMANN, J. 1974. Observational study of behavior: sampling methods. Behavior 49: 227-265.

CARLETON, M.D. \& OLSON, S.L. 1999. Amerigo Vespucci and the rat of Fernando de Noronha: a new genus and species of Rodentia (Muridae: Sigmodontinae) from a volcanic island off Brazil's continental shelf. Am. Mus. Novit. 3256:1-59.

CRESSEY, R.F. \& LACHNER, E.A. 1970. The parasitic copepod diet and life history of diskfishes (Echeneidae). Copeia 1970: 310-318.
FERTL, D. \& LANDRY, JR., A.M. 1999. Sharksucker (Echeneis naucrates) on a bottlenose dolphin (Tursiops truncatus) and a review of other cetacean-remora associations. Mar. Mamm. Sci. 15: 859-863.

FOLLETT, W.I. \& DEMPSTER, L.J. 1960. First records of the echeneidid fish Remilegia australis (Bennett) from California, with meristic data. Proc. Calif. Acad. Sci. 31: 169-184.

GASPARINI, J.L. \& SAZIMA, I. 1996. A stranded melonheaded whale, Peponocephala electra, in southeastern Brazil, with comments on wounds from the cookiecutter shark Isistius brasiliensis. Mar. Mamm. Sci. 12: 308-312.

HELFMAN, G.S., COLLETTE, B.B. \& FACEY, D.E., 1997. The diversity of fishes. Blackwell Science, Malden, Massachussets.

JONES, E.C. 1971. Isisitius brasilienis, a squaloid shark, the probable cause of crater wounds on fishes and cetaceans. Fish. Bull. 69: 791-798.

KATONA, S. \& WHITEHEAD, H. 1988. Are Cetacea ecologically important? Oceanogr. Mar. Biol. Annu. Rev. 26: 553-568.

LEHNER, P.N. 1979. Handbook of ethological methods. Garland STPM Press, New York.

LODI, L. \& FIORI, B. 1987. Observações sobre o comportamento do golfinho-rotador; Stenella longirostris (Cetacea, Delphinidae) na Ilha de Fernando de Noronha - Brasil. In Anais da 2a Reunião de Trabalho de Especialistas em Mamíferos Aquáticos da América do Sul. Rio de Janeiro, Brazil, p. 60-68.

MAIDA, M. \& FERREIRA, B.P. 1997. Coral reefs of Brazil: an overview. Proc. Int. Coral Reef Symp. 8: 263-274.

NORRIS K.S., WÜRSIG, B., WELLS, R.S., WÜRSIG, M., WÜRSIG, M. 1994. The Hawaiian spinner dolphin. University of California Press, Berkeley.

RADFORD, K.W. \& KLAWE, W.L. 1965. Biological observations on the whalesucker, Remilegia australis Echeneiformes: Echeneidae. Trans. San Diego Soc. Nat. Hist. 14: 67-72.

RICE, D.W. \& CALDWELL, D.K. 1961. Observations on the habits of the whalesucker, Remilegia australis. Norsk Hvalfangst-tid. 5: 181-189.

SAZIMA, I., SAZIMA, C. \& SILVA-JR J.M. 2003. The cetacean offal connection: feces and vomits of spinner dolphins as a food source for reef fishes. Bull. Mar. Sci. 72(1): 151-160.

SILVA-JR. J. M. , SILVA F. J. L. \& PEREIRA J. A. 1996. O comportamento do golfinho rotador em F. de Noronha. Anais 14 Encontro Anual de Etologia: 251-262.

STRASBURG, D.W. 1959. Notes on the diet and correlating structures of some central Pacific echeneid fishes. Copeia 1959: 244-248. 
TOMÁS, A.R.G. \& GOMES, U.L. 1989. Observações sobre a presença de Cetorhinus maximus (Gunnerus, 1765) (Elasmobranchii, Cetorhinidae) no sudeste e sul do Brasil. Bol. Inst. Pesca 16: 111-116.

WÜRSIG, B. \& JEFFERSON, T.A. 1990. Methods of photoidentification for small cetaceans. In: Individual recognition of cetaceans: use of photo-identification and other techniques to estimate population parameters (P.S. Hammond, S.A. Mizroch \& G.P. Donovan, eds.). International Whaling Commission, Cambridge, p.43-52.

Title: Whalesuckers and a spinner dolphin bonded for weeks: does host fidelity pay off?

Authors: José Martins Silva-Jr and Ivan Sazima

Biota Neotropica, Vol. 3 ( number 2: 2003

http://www.biotaneotropica.org.br/v3n2/pt/ abstract?short-communication+BN01303022003

Date Received 07/16/2003

Revised 09/30/2003

Accepted 10/24/2003

ISSN 1676-0611

http://www.biotaneotropica.org.br 